\title{
PENGARUH DOSIS PUPUK ORGANIK CAIR KULIT NANAS TERHADAP PERTUMBUHAN BIBIT KELAPA SAWIT (Elaeis guineensis Jacq.) DI PRE NURSERY
}

\author{
Oleh : \\ Hendro Kartiko *) \\ Darwati Susilastuti **) \\ M. Husni ${ }^{* * *}$ ) \\ Email:kartikohendro858@gmail.com
}

\begin{abstract}
ABSTRAK
Ketersediaan tanah subur saat ini untuk media pembibitan sangat terbatas. Rendahnya ketersediaan unsur hara dapat menjadi faktor penghambat di pembibitan. Untuk proses pembibitan ini, salah satu faktor penentunya adalah pemupukan. Upaya untuk meningkatkan efektivitas, pemupukan perlu dilakukan agar pertumbuhan tanaman dapat ditingkatkan. Limbah kulit nanas yang tidak terkendalikan yang kemudian berdampak negatif yang akan mempengaruhi berbagai segi kehidupan, baik secara langsung maupun tidak langsung. Permasalahan lingkungan yang terjadi adalah menjadi sumber bakteri penyakit, pencemaran udara, tanah, air, dan lebih jauh lagi terjadinya bencana ledakan gas metan. Penelitian ini bertujuan untuk mengetahui bagaimana pengaruh pupuk organik cair kulit nanas dan berapa dosis pupuk organik cair kulit nanas yang dapat memberikan pengaruh terhadap pertumbuhan bibit tanaman kelapa sawit (Elaeis guineensis Jacq.) di Pre nursery. Pelaksanaan penelitian ini dilaksanakan di rumah bibit, di Kecamatan Cikarang Barat, Kabupaten Bekasi pada bulan April - Juli 2021. Penelitian menggunakan Rancangan Acak Kelompok (RAK) yang terdiri dari 1 faktor yaitu dosis POC kulit nanas (A) dan terdiri dari 6 taraf, yaitu: A0 : Dosis POC kulit nanas $0 \mathrm{ml} / \mathrm{L}, \mathrm{A} 1$ : Dosis POC kulit nanas $10 \mathrm{ml} / \mathrm{L}, \mathrm{A} 2$ : Dosis POC kulit nanas $20 \mathrm{ml} / \mathrm{L}, \mathrm{A} 3$ : Dosis POC kulit nanas $30 \mathrm{ml} / \mathrm{L}, \mathrm{A} 4$ : Dosis POC kulit nanas $40 \mathrm{ml} / \mathrm{L}$, A5 : Dosis POC kulit nanas $50 \mathrm{ml} / \mathrm{L}$. Dimana setiap perlakuan diulang sebanyak 3 kali dan setiap ulangan masing masing berjumlah 5 tanaman sampel. Hasil penelitian menunjukan pemberian pupuk organik cair kulit nanas memberikan pengaruh nyata hingga sangat nyata terhadap morfologi (tinggi tanaman, diameter batang, dan panjang akar) dan fisiologi (biomassa pertumbuhan) bibit tanaman kelapa sawit (Elaeis guineensis Jacq.) di Pre nursery. Pemberian dosis $50 \mathrm{ml} / \mathrm{L}$ pupuk organik cair kulit nanas memberikan hasil terbaik terhadap parameter tinggi bibit 1-3 BST $(7,06 \mathrm{~cm}, 16,70 \mathrm{~cm}$ dan 22, $30 \mathrm{~cm})$, diameter batang 1 BST (3,48 cm), jumlah daun 1-3 BST (2,06 helai, 3,06 helai dan 4,44 helai), panjang akar (20,50 $\mathrm{cm})$, dan bobot kering $(2,82 \mathrm{~cm})$.
\end{abstract}

Kata kunci : Kelapa sawit, Kulit nanas, POC.

\begin{abstract}
Currently, the availability of fertile soil for nursery media is very limited. The low availability of nutrients can be an inbibiting factor in nurseries. For this nursery process, one of the determining factors is fertilization. Efforts to increase effectiveness, fertilization needs to be done so that plant growth can be increased. Pineapple skin waste that is not controlled which then has a negative impact that will affect various aspects of life, either directly or indirectly. Environmental problems that occur are a source of disease bacteria, air, soil, water pollution, and furthermore the occurrence of a methane gas explosion disaster. This study aims to determine the effect of liquid organic fertilizer on pineapple peel and how many doses of liquid organic fertilizer for pineapple peel can affect the growth of oil palm (Elaeis guineensis Jacq.) seedlings in the Pre
\end{abstract}


nursery. The implementation of this research was carried out in a nursery house, in West Cikarang District, Bekasi Regency in April - July 2021. The study used a Randomized Block Design (RAK) which consisted of 1 factor, namely the dose of POC pineapple peel (A) and consisted of 6 levels, namely : AO : Pineapple peel POC dose $0 \mathrm{ml} / \mathrm{L}, A 1$ : pineapple peel POC dose $10 \mathrm{ml} / \mathrm{L}, A 2$ : pineapple peel POC dose 20 $\mathrm{ml} / \mathrm{L}, A 3$ : pineapple peel POC dose $30 \mathrm{ml} / \mathrm{L}$, A4 : peel POC dose pineapple $40 \mathrm{ml} / \mathrm{L}$, A5 : Pineapple peel POC dose $50 \mathrm{ml} / \mathrm{L}$. Where each treatment was repeated 3 times and each replication consisted of 5 sample plants. The results showed that the application of liquid organic fertilizer of pineapple peel had a significant to very significant effect on the morphology (plant height, stem diameter, and root length) and physiology (biomass growth) of oil palm (Elaeis guineensis Jacq.) seedlings in the Pre-nursery. Giving a dose of $50 \mathrm{ml} / \mathrm{L}$ of liquid organic fertilizer of pineapple peel gave the best results for the parameters of seedling height 1-3 BST $(7.06 \mathrm{~cm}, 16.70 \mathrm{~cm}$ and $22.30 \mathrm{~cm})$, stem diameter 1 BST $(3.48 \mathrm{~cm})$, number of leaves 1-3 BST (2.06 strands, 3.06 strands and 4.44 strands), root length $(20.50 \mathrm{~cm})$, and dry weight $(2.82 \mathrm{~cm})$.

Keywords: Oil palm, Pineapple peel, POC.

*) Mahasiswa Program Studi Agroteknologi, Fakultas Pertanian, Universitas Borobudur.

**) Dosen Pembimbing I, Fakultas Pertanian, Universitas Borobudur.

***) Dosen Pembimbing II, Fakultas Pertanian, Universitas Borobudur. 


\section{PENDAHULUAN}

Kebutuhan CPO (Crude Palm Oi) di dunia ini setiap harinya semakin meningkat. Hal ini karena, banyaknya produk yang mulai menggunakan minyak sawit sebagai kebutuhan bahan baku utama. PASPI (2014), menyatakan bahwa produk industri kelapa sawit ini sangat berperan penting untuk membangun perekonomian daerah dengan peningkatan pendapatan petani dan menjadi salah satu sumber devisa bagi negara. Berdasarkan data dari Ditjenbund (2018), menyatakan bahwa Indonesia merupakan sebagai negara produsen industri minyak kelapa sawit yang terbesar di dunia. Pada tahun 2018, produksi CPO ini Indonesia mencapai hingga sebesar 27,35 juta ton. Oleh karen itu, keberhasilan produksi kelapa sawit tersebut sangat ditentukan oleh sutau penerapan teknis budidaya yang tepat, salah satunya adalah kegiatan pembibitan dan tingkat pertumbuhannya.

Pada saat ini mendapatkan tanah subur untuk media pembibitan sangat sulit. Hal ini karena, kandungan unsur hara tersebut sangat rendah sehingga media tanaman menjadi salah satu faktor penghambat di pembibitan. Untuk proses pembibitan ini, salah satu faktor penentunya adalah pemupukan. Arizka et al., (2013) mengatakan kandungan pupuk yang terdiri dari unsur hara makro dan mikro dalam dosis tepat dapat meningkatkan efisiensi pemupukan. Penggolongan pupuk menurut sumber bahan yang digunakan adalah pupuk organik dan anorganik. Pupuk yang sering digunakan di perkebunan kelapa sawit adalah pupuk anorganik, dampak negatif dari penggunaan pupuk anorganik itu sendiri berdampak buruk bagi lingkungan. Hal ini sejalan dengan pernyataan Widyaswari et al. (2017) mengatakan penyebab utama menurunnya produktivitas tanaman adalah menurunnya kesuburan tanah karena aplikasi pupuk anorganik yang berlebih dan terus menerus. Oleh karena itu perlu suatu cara untuk tetap menjaga dan memperbaiki kesuburan tanah, salah satu cara yang dapat dilakukan adalah dengan memberikan pupuk organik pada tanah. Pupuk organik memiliki dua jenis yaitu Pupuk Organik Cair (POC) dan pupuk organik padat (Mazaya et al., 2013).

Salah satu jenis pupuk yang dibutuhkan oleh tanaman dan mudah ditemukan dipasaran adalah pupuk organik cair. Daun tempat kandungan hara makro dan mikro esensial (N, P, K, S, Ca, Mg, B, Mo, Cu, Fe, Mn, dan bahan organik) sehingga cocok sebagai tempak pengaplikasian pupuk organik cair. Pupuk organik cair ini berperan dapat meningkatkan dan mendorong pembentukan pada klorofil daun sehingga proses fotosintesis pada tanaman dapat meningkat serta terjadinya penyerapan nitrogen dari udara. Bahkan dapat meningkatkan vigor tanaman sehingga tanaman menjadi kokoh dan kuat, meningkatkan daya tahan tanaman terhadap kekeringan, merangsang pertumbuhan cabang produksi, meningkatkan pembentukan bunga dan bakal buah, mengurangi gugurnya dan, bunga, dan bakal buah (Huda, 2013). Pengaplikasian pupuk organik cair dengan konsetrasi $50 \mathrm{ml} / \mathrm{L}$ dapat memberikan pengaruh terbaik terhadap hasil pertumbuhan bibit tanaman kelapa sawit. Pernyataan itu sejalan dengan dengan hasil penelitian Sulardi, (2019) menyatakan bahwa 
pengunaan POC dengan konsentrasi $50 \mathrm{ml} / \mathrm{L}$ mampu memberikan pengaruh nyata terhadap pembibitan tanaman kelapa sawit (Elaeis guineensis Jacq) di Pre nursery pada parameter tinggi tanaman $(\mathrm{cm})$. Selain itu untuk meningkatkan efesiensi pemupukan dapat dilakukan dengan mengelola sistem pemupukan misalnya pemberian pupuk organik cair kulit nanas yang diketahui memiliki beberapa unsur hara yang dibutuhkan oleh tanaman (Sriagtula dan Sowmen, 2018).

Kulit nanas merupukan limbah organik dari buah nanas yang sudah tidak bisa dimakan dan mudah untuk didapatkan, bisa dimanfaatkan sebagai bahan pembuatan POC.Apabila kulit limbah nanas ini tidak dapat dikelola dengan benar, baik secara langsung ataupun tidak langsung maka akan sangat berdampak negatif terhadap lingkungan bagi segi kehidupan. Dampak negatif pada lingkungan dapat munculnya sumber bakteri penyakit, pencemaran tanah, air dan udara bahkan jauh lebih berdampak terjadinya bencana ledakan gas metan. Limbah kulit nanas ini banyak mengandung senyawa-senyawa yang dapat diolah menjadi produk olahan yang bermanfaat. Oleh karena itu, dengan adanya kadar nutrisi yang cukup tinggi sehingga dapat dijadikan sebagai bahan pembuatan pupuk organic cair. Berdasarkan hasil penelitian Susi et al., (2018) menyatakan bahwa di dalam pupuk organik cair dari kulit nanas mengandung bebrapa unsur hara diantaranya P 23,63 ppm, K 08,25 ppm, N 01,27 \%, Ca 27,55 ppm, Mg 137,25 ppm, Na 79,52 ppm, Na 79, 52 ppm, Fe 1,27 ppm, Mn 28,75 ppm, Cu 0,17 ppm, Zn 0,53 ppm dan C Organik 3,10 \%.

Untuk mendapatkan hasil pemupukan yang bagus sebaiknya dilakukan secara tepat dan sesuai dosis yang dianjurkan, karena pemberian pupuk yang berlebihan akan menyebabkan keracunan pada tanaman. Apabila proses pemupukan ini tidak sesuai dengan defenisi tersebut maka hasilnya yang diperoleh pun tidak akan optimal. Upaya untuk mengendalikan permasalahan tersebut salah satunya dengan memperhatikan aspek pada prinsip pengaplikasian adalah dosis. Dengan memberikan dosis tepat maka akan menentukan manfaat dari unsur tersebut tetapi apabila kurang atau berlebihan dari dosis anjuran tersebut maka pertumbuhan tanaman kemungkinan akan semakin tidak tidak optimal (Rina, 2020).

Berdasarkan uraian di atas maka perlu dilakukan suatu percobaan terhadap aplikasi penggunaan pupuk organik cair limbah kulit nanas sebagai upaya untuk meningkatkan pertumbuhan bibit tanaman kelapa sawit. Penelitian ini bertujuan untuk mengetahui pengaruh dosis pupuk organik cair kulit nanas terhadap pertumbuhan bibit tanaman kelapa sawit (Elaeis guineensis Jacq.) di Pre nursery agar menghasilkan pertumbuhan yang optimal. Sedangkan manfaat penelitian ini untuk menambah informasi mengenai penggunaan kulit nanas sebagai bahan pembuatan Pupuk Organik Cair (POC) sebagai upaya mengurangi atau meminimalisir penggunaan pupuk kimia dan dampak negatif terhadap lingkungan sehingga dapat dijadikan alternatif pupuk organik cair untuk pembibitan tanaman kelapa sawit (Elaeis guineensis Jacq.) di Pre nursery. 


\section{METODE PENELITIAN}

\section{Tempat dan Waktu Penelitian}

Penelitian ini dilaksanakan di rumah bibit, Perumahan Taman Aster Cluster Lotus Blok A3/214, Kecamatan Cikarang Barat, Kabupaten Bekasi. Penelitian ini dilaksanakan pada bulan April - Juli 2021 (Selama 4 Bulan).

\section{Alat dan Bahan}

Alat-alat yang digunakan dalam penelitian ini adalah lakban, lem tembak, selang, botol bekas, polybag ukuran $18 \times 18 \mathrm{~cm}$, cangkul, tumbukan, ember, embrat, timbangan, gelas ukur, jangka sorong, meteran, kantong plastik, kertas label, oven dan alat tulis. Sedangkan bahan-bahan yang digunakan dalam penelitian ini adalah kompos kotoran hewan (45 kg), sub soil (45 kg), pupuk NPK (8 g), kecambah kelapa sawit varietas PPKS (90 butir), fungisida Antracol (20 ml), kulit nanas (5 kg), air kelapa 10 butir, gula jawa (1 kg), air (5 L), dan EM4 (250 ml).

\section{Rancangan Penelitian}

Rancangan yang digunakan pada penelitian ini adalah Rancangan Acak Kelompok (RAK) yang terdiri dari 1 faktor yaitu dosis pupuk organik cair kulit nanas (A) dimana setiap perlakuan diulang sebanyak 3 kali dan Setiap ulangan masing masing berjumlah 5 tanaman sampel. Penelitian yang diujikan pada penelitian ini adalah:

A0 : Dosis POC kulit nanas $0 \mathrm{ml} / \mathrm{L}$

A1 : Dosis POC kulit nanas $10 \mathrm{ml} / \mathrm{L}$

A2 : Dosis POC kulit nanas $20 \mathrm{ml} / \mathrm{L}$

A3 : Dosis POC kulit nanas $30 \mathrm{ml} / \mathrm{L}$

A4 : Dosis POC kulit nanas $40 \mathrm{ml} / \mathrm{L}$

A5 : Dosis POC kulit nanas $50 \mathrm{ml} / \mathrm{L}$

Pada penelitian ini terdiri dari 18 satuan percobaan. Setiap satuan percobaan terdiri dari 5 sampel sehingga di dapatkan 90 polybag. Setiap perlakuan ditempatkan pada satuan percobaan dengan cara diacak. Tata letak percobaan ditampilkan pada lampiran 1. Model rancangan percobaan yang akan dilakukan adalah sebagai berikut:

Keterangan :

$$
Y_{i j}=\mu+\tau_{i}+\beta_{j}+\varepsilon_{i j}
$$

Yij = Pengamatan pada perlakuan POC kulit nanas ke-i dan kelompok ke-j

$\mu \quad=$ Rataan umum

$\tau_{\mathrm{i}} \quad=$ Pengaruh perlakuan ke- $\mathrm{i}$

$\beta_{j} \quad=$ Pengaruh kelompok ke- $j$

$\varepsilon_{\mathrm{ij}} \quad=$ Pengaruh galat pada perlakuan ke-i dengan ulangan ke-j

i $\quad=1,2,3,4,5$ dan 6

$\mathrm{j}=1,2$, dan 3 
Berdasarkan penelitin Madusari et al., 2021 model rangcangan percobaan yang dilakukan dalam penelitian Evaluasi dan Aplikasi Pupuk Organik Cair Larva Black Soldier Fly pada Pembibitan Awal bibit Kelapa Sawit (Elaeis guineensis Jacq.). digunakan rancangan acak kelompok (RAK).

\section{Parameter yang diamati}

Pengamatan dilakukan terhadap tinggi tanaman, jumlah daun, diameter batang, panjang akar, biomassa tanaman. Pengamatan dilakukan pada 1 BST, 2 BST, 3 BST. Perubahan yang diamati meliputi:

1. Tinggi tanaman dihitung dari 1 BST sampai 3 BST

2. Jumlah daun, dihitung dari 1 BST sampai 3 BST

3. Diameter natang, dihitung dari 1 BST sampai 3 BST

4. Panjang akar dihitung pada saat panen

5. Bobot basah dihitung berat per tanaman dari pangkal batang hingga daun pada saat panen.

6. Bobot kering dihitung per tanaman setelah pengeringan dimasukkan ke dalam oven selama 48 jam dengan suhu $80^{\circ} \mathrm{C}$.

\section{HASIL DAN PEMBAHASAN}

\section{Kondisi Umum}

Pertumbuhan bibit kelapa sawit yang optimal bergantung pada jenis pupuk dan dosis pupuk yang digunakan. Penelitian ini dilakukan pada bulan Maret 2021 - Juli 2021. Pada tahun 2021, suhu di Kabupaten Bekasi berkisar $27^{\circ}-33^{\circ}$ celcius dengan kelembapan 50\% (BMKG, 2021). Hal ini sesuai dengan ketentuan syarat tumbuh kelapa sawit. Pahan (2015) menyatakan bahwa suhu optimum untuk pertumbuhan kelapa sawit adalah $29^{\circ} \mathrm{C}-30^{\circ} \mathrm{C}$, dengan intensitas penyinaran matahari sekitar $5-7$ jam/hari dan kelembapan optimum yang ideal sekitar $80-90 \%$.

Gulma yang dominan muncul pada saat penelitian adalah gulma rumput teki (Cyperus rotundus) dan meniran (Phyllantus urinaria). Pengendalian gulma di dalam dan di luar polybag dilakukan sekali dalam satu minggu. Pengendalian gulma di dalam polybag dilakukan secara manual yaitu membersihkan gulma hanya menggunakan tangan, sedangkan di luar polybag dilakukan secara mekanis yaitu menggunakan cangkul. Pengendalian ini dilakukan karena keberadaan gulma pada areal pembibitan dapat menyebabkan persaingan terhadap tanaman utama dalam memperebutkan unsur hara sehingga dapat menyebabkan terhambatnya pertumbuhan tanaman utama. 


\section{Kandungan Hara N, P, K dan C-Organik POC Kulit Nanas}

Hasil analisis kandungan hara N, P, K dan C-Organik pada POC kulit nanas dapat dilihat pada Tabel 1.

Tabel 1. Hasil analisis kandungan hara N, P, K dan C-Organik POC kulit nanas.

\begin{tabular}{ccccc}
\hline \multirow{2}{*}{ Pupuk } & \multicolumn{4}{c}{ Parameter Pengamatan (\%) } \\
\cline { 2 - 5 } & $\mathbf{N}$ & $\mathbf{P}$ & $\mathbf{K}$ & C-Organik \\
\hline POC kulit nanas & 1.12 & 0.20 & 1.24 & 3.51 \\
\hline
\end{tabular}

Sumber : Laboratorium Penguji Departemen Agronomi dan Hortikultura, Fakultas Pertanian, Institut Pertanian Bogor.

Hasil uji labolatorium POC kulit nanas memiliki kandungan unsur hara Nitrogen $(\mathrm{N})$, Posfor $(\mathrm{P})$, Kalium $(\mathrm{K})$ dan C-Organik. Unsur hara makro N,P,K memiliki fungsi untuk meransang pertumbuhan tanaman dan meningkatkan kapasitas tukar kation (KTK) pada tanah. Nitrogen $(\mathrm{N})$ berfungsi untuk merangsang proses pertumbuhan vegetatif pada warna hijau daun dan pertumbuhan tanaman tersebut secara keseluruhan dengan mensintesa asam amino serta protein dalam tanaman. Bagi tanaman fosfor $(\mathrm{P})$ berfungsi pada proses pengangkutan energi hasil metabolisme dalam tanaman, pembentukan biji dan pertumbuhan akar, pembelahan sel tanaman dan memperbesar 9 jaringan sel serta merangsang pembungaan dan pembuahan. Sedangkan kalium (K) berfungsi untuk memproses pada organik karbon, pengangkutan hasil asimilasi, enzim dan mineral, fotosintesa dan termasuk air bahkan dapat meningkatkan daya tahan atau kekebalan tanaman terhadap penyakit (Netiana, 2019).

Berdasarkan hasil analisis kandungan C-Organik, N, P dan K pada POC kulit nanas yang tertera pada Tabel 1 . Persentase untuk tiap unsur hara memiliki nilai COrganik (3,51\%), N Total (1,12\%), P (0,20\%) dan K (1,24\%). Hal ini dikarenakan campuran pada pembuatan POC kulit nanas yang menggunakan, air kelapa, gula merah dan EM4. Air kelapa banyak mengandung mineral antara lain natrium $(\mathrm{Na})$, kalsium $(\mathrm{Ca})$, magnesium $(\mathrm{Mg})$, ferum $(\mathrm{Fe})$, cuprum $(\mathrm{Cu})$, posfor $(\mathrm{P})$ dan sulfur $(\mathrm{S})$. Selain kaya mineral, air kelapa juga mengandung gula antara 1,7 gram sampai 2,6\%, protein 0,07 hingga $0,55 \%$ dan mengandung berbagai macam vitamin seperti asam sitrat, asam nikotina, asam pantotenal, asam folat, niacin, riboflavin, thiamin dan terdapat dua hormon alami yaitu auksin dan sitokinin yang berperan penting dalam proses pertumbuhan dan jumlah daun pada tanaman (Manurung et al., 2017). Pembuatan pupuk cair ini juga menggunakan EM-4 yang terdiri dari campuran mikroorganisme antara lain Lactobacillus sp, bakteri fosfat, streptomyces, ragi (Saccharomyces cerevisiae) dan unsur esensial lainnya dibutuhkan tanaman yang berperan dalam mempercepat proses fermentasi bahan organik sehingga unsur hara yang terkandung akan terserap dan tersedia bagi tanaman (Hadisuwito, 2012).

Menurut Standar Nasional Indonesia (SNI 19-7030-2004) menyatakan bahwa syarat minimal untuk pupuk cair adalah N (0,40\%), P (0,10\%), K (0,20\%). Hal ini menyatakan bahwa kandungan hara $\mathrm{N}, \mathrm{P}$, dan $\mathrm{K}$ yang terkandung dalam POC kulit nanas telah memenuhi syarat. Berdasarkan penelitian yang dilakukan oleh Madusari 
(2021) mengenai hasil uji POC limbah kulit nenas mengandung C-Organik (3,50\%), N Total $(0,17 \%), \mathrm{P}(0,20 \%)$ dan K $(0,033 \%)$.

\section{Tinggi Bibit (cm)}

Berdasarkan hasil analisis statistik menunjukkan bahwa perlakuan POC kulit nanas berpengaruh nyata terhadap tinggi bibit tanaman kelapa sawit pada umur 1 BST dan sangat berpengaruh nyata pada 2 dan 3 BST. Rataan tinggi bibit tanaman kelapa sawit dengan pemberian POC kulit nanas dapat dilihat pada tabel 2.

Tabel 2. Rataan tinggi bibit tanaman kelapa sawit dengan pemberian POC kulit nanas.

\begin{tabular}{cccc}
\hline \multirow{2}{*}{ Perlakuan } & \multicolumn{3}{c}{ Tinggi bibit $(\mathbf{c m})$} \\
\cline { 2 - 4 } & $\mathbf{1}$ & $\mathbf{2}$ & $\mathbf{3}$ \\
\cline { 2 - 4 } & $6,18 \mathrm{~b}$ & $13,56 \mathrm{~d}$ & $19,76 \mathrm{~d}$ \\
Kontrol & $6,18 \mathrm{~b}$ & $13,48 \mathrm{~d}$ & $20,46 \mathrm{~d}$ \\
$10 \mathrm{ml} / \mathrm{L}$ & $6,35 \mathrm{~b}$ & $14,16 \mathrm{c}$ & $20,16 \mathrm{c}$ \\
$20 \mathrm{ml} / \mathrm{L}$ & $6,36 \mathrm{~b}$ & $15,73 \mathrm{~b}$ & $21,20 \mathrm{~b}$ \\
$30 \mathrm{ml} / \mathrm{L}$ & $6,95 \mathrm{a}$ & $15,51 \mathrm{~b}$ & $21,83 \mathrm{a}$ \\
$40 \mathrm{ml} / \mathrm{L}$ & $7,06 \mathrm{a}$ & $16,70 \mathrm{a}$ & $22,30 \mathrm{a}$ \\
\hline $50 \mathrm{ml} / \mathrm{L}$ & &
\end{tabular}

Keterangan : Angka yang diikuti huruf yang tidak sama pada kolom yang sama berbeda nyata menurut uji DMRT 5\%.

Berdasarkan hasil rata-rata tinggi tanaman yang disajikan pada Tabel 2. di atas dapat dilihat bahwa pemberian POC kulit nanas berpengaruh nyata terhadap tinggi bibit tanaman kelapa sawit pada umur pengamatan 1 BST. Diumur 1 BST mendapatkan hasil tertinggi bibit tanaman kelapa sawit pada perlakuan A5 $50 \mathrm{ml} / \mathrm{L}$ $(7,06 \mathrm{~cm})$ berbeda nyata dengan perlakuan A0 kontrol $(6,18 \mathrm{~cm})$, A1 $10 \mathrm{ml} / \mathrm{L}(6,18$ $\mathrm{cm})$, A2 $20 \mathrm{ml} / \mathrm{L}(6,35 \mathrm{~cm})$, A3 $30 \mathrm{ml} / \mathrm{L}(6,36 \mathrm{~cm})$, namun tidak berbeda nyata dengan perlakuan A4 $40 \mathrm{ml} / \mathrm{L}(6,95 \mathrm{~cm})$. Menurut Hidayat (2013) menyatakan bahwa pada pertambahan tinggi tanaman kelapa sawit ini sangat erat kaitannya dengan nitrogen $(\mathrm{N})$ sebagai unsur hara makro. Sehingga dengan adanya kandungan unsur (N) pada kandungan POC dari kulit nanas tersebut dapat berpengaruh terhadap pertambahan tinggi tanaman kelapa sawit. Karena unsur hara nitroge $(\mathrm{N})$ berperan untuk merangsang pertumbuhan vegetatif dengan bertambahnya tinggi tanaman pada kelapa sawit. Hal ini, pertumbuhan tinggi tanaman terjadi karena adanya peristiwa pembelahan dan perpanjangan sel yang didominasi pada ujung pucuk tanaman kelapa sawit. Proses ini merupakan sintesa protein yang diperoleh tanaman dari lingkungan karena adanya bahan organik dalam suatu media (Sulardi, 2019). Penambahan bahan organik yang mengandung nitrogen $(N)$ dapat mempengaruhi kadar nitrogen total dan membantu mengaktifkan sel-sel tanaman serta mempertahankan suatu jalannya proses fotosintesis sehingga pertumbuhan tinggi tanaman pada kelapa sawit sangat berpengaruh.

Pada umur 2-3 BST, perlakuan terbaik A5 $50 \mathrm{ml} / \mathrm{L}$ POC kulit nanas dengan rata-rata ketinggian $(22,30 \mathrm{~cm})$ yang berbeda nyata dengan perlakuan A0 kontrol $(19,76 \mathrm{~cm})$, A1 $10 \mathrm{ml} / \mathrm{L}(20,46 \mathrm{~cm})$, A2 $20 \mathrm{ml} / \mathrm{L}(20,16 \mathrm{~cm})$, A3 $30 \mathrm{ml} / \mathrm{L}(2021 \mathrm{~cm})$, 
namun tidak berbeda nyata dengan perlakuan A4 $40 \mathrm{ml} / \mathrm{L}(22,30 \mathrm{~cm})$. Pertumbuhan tinggi bibit tanaman kelapa sawit ini sangat berkaitan dengan unsur hara makro nitrogen $(\mathrm{N})$ karena dapat mendorong atau terpacunya sel di ujung batang untuk segera mempercepat mengadakan pembelahan dan pembesaran sel terutama di daerah meristematis dan terpacunya sintesis serta pembelahan dinding sel yang didominasi sintesis, karen pembelahan dinding sel ini didominasi dibagian ujung pucuk tanaman (Istiqomah, 2014).

Suwahyono (2011) menyatakan bahwa pada awal pertumbuhan tanaman sangat dipengaruhi oleh adanya ketersediaan unsur nitrogen $(\mathrm{N})$ karena untuk melakukan pertumbuhan vegetatif pada daun, batang dan akar. Apabila unsur hara $\mathrm{N}$ tercukupi, maka hormon auksin akan terpacu untuk bekerja sehingga akan mempengaruhi pertumbuhan tinggi tanaman. Makmur (2018) menyatakan bahwa pertumbuhan dan perkembangan tanaman dipengaruhi oleh kegiatan yang berlangsung dalam sel dan jaringan tanaman. Tanaman tumbuh subur apabila segala unsur hara yang dibutuhkan tersebut tercukupi atau tersedia dalam bentuk yang sesuai sehingga akan diserap.

\section{Diameter Batang (cm)}

Berdasarkan hasil analisis statistik menunjukkan bahwa perlakuan POC kulit nanas tidak berpengaruh nyata terhadap diameter bibit tanaman kelapa sawit pada umur 1 BST dan sangat berpengaruh nyata pada 2 dan 3 BST. Rataan diameter batang bibit tanaman kelapa sawit dengan pemberian POC kulit nanas dapat dilihat pada tabel 3 .

Tabel 3. Rataan diameter batang bibit tanaman kelapa sawit dengan pemberian POC kulit nanas.

\begin{tabular}{cccc}
\hline \multirow{2}{*}{ Perlakuan } & \multicolumn{3}{c}{ Diameter batang $\mathbf{( c m})$} \\
\cline { 2 - 4 } & \multicolumn{3}{c}{ Bulan setelah tanam } \\
\cline { 2 - 4 } & 3,44 & $5,12 \mathrm{c}$ & $\mathbf{3}$ \\
\hline Kontrol & 3,24 & $5,06 \mathrm{c}$ & $6,68 \mathrm{c}$ \\
$10 \mathrm{ml} / \mathrm{L}$ & 3,23 & $5,13 \mathrm{c}$ & $6,57 \mathrm{c}$ \\
$20 \mathrm{ml} / \mathrm{L}$ & 3,38 & $5,36 \mathrm{~b}$ & $7,34 \mathrm{~b}$ \\
$30 \mathrm{ml} / \mathrm{L}$ & 3,32 & $5,85 \mathrm{a}$ & $8,09 \mathrm{a}$ \\
$40 \mathrm{ml} / \mathrm{L}$ & 3,48 & $5,81 \mathrm{a}$ & $8,07 \mathrm{a}$ \\
$50 \mathrm{ml} / \mathrm{L}$ & 5, &
\end{tabular}

Keterangan : Angka yang diikuti huruf yang tidak sama pada kolom yang sama berbeda nyata menurut uji DMRT 5\%.

Dapat dilihat bahwa pemberian POC kulit nanas tidak berpengaruh nyata terhadap diameter batang bibit tanaman kelapa sawit pada umur pengamatan 1 MST. Hal ini terjadi karena masih sedikitnya jumlah daun pada bibit tanaman kelapa sawit. Suryati et al., (2014) mengatakan pada umumnya semakin tinggi batang dan banyak jumlah daun, maka organ-organ lain seperti diameter batang semakin baik pula. Daun merupakan faktor penting dalam menekan laju fotosintesis sehingga diameter batang yang dihasilkan akan lebih besar. Hal ini dijelaskan oleh Selvia et al., (2014) 
bahwa batang merupakan daerah akumulasi pertumbuhan tanaman sehingga bentuk dan jumlah daun dapat mendorong laju fotosintesis.

Pada umur 2-3 BST, didapat hasil diameter batang bibit tanaman kelapa sawit pada perlakuan A5 $50 \mathrm{ml} / \mathrm{L}(8,07 \mathrm{~cm})$ yang berbeda nyata dengan perlakuan A0 kontrol $(6,68 \mathrm{~cm})$, A1 $10 \mathrm{ml} / \mathrm{L}(6,69 \mathrm{~cm})$, A2 $20 \mathrm{ml} / \mathrm{L}(6,57 \mathrm{~cm})$, dan A3 $30 \mathrm{ml} / \mathrm{L}$ $(7,34 \mathrm{~cm})$, namun tidak berbeda nyata dengan perlakuan A4 $40 \mathrm{ml} / \mathrm{L}(8,09 \mathrm{~cm})$. kulit pisang kepok (A3). Hal tersebut mungkin dikarenakan POC kulit nanas kandungan unsur haranya terkhusus $\mathrm{P}$ sudah cukup atau terpenuhi sehingga dapat melakukan pertumbuhan batang yang maksimal. Hiderssah et al., (2014) mengatakan bahwa unsur hara $\mathrm{P}$ sangat penting karena dapat meningkatkan pertambahan diameter batang bibit tanaman kelapa sawit. Unsur hara $\mathrm{P}$ akan merangsang perakaran tanaman sehingga akar akan lebih baik dalam menyerap unsur hara dan pembentukan jaringan baru termasuk pertambahan diameter batang.

Selain unsur hara $\mathrm{P}$ ada juga unsur hara $\mathrm{K}$ yang mempengauhi pertumbuhan batang. Menurut Waruwu et al. (2018) peran kalium dalam mendorong lajunya pertumbuhan jaringan meristematik dan membuat batang menjadi kuat. $\mathrm{K}$ yang cukup mampu menstimulus terbentuknya karbohidrat secara optimal dan proses translokasi pati ke lingkar batang sawit akan semakin laju, membuat pembentukan lingkar batang semu kelapa sawit berjalan lancar. Sejalan dengan pernyataan Setyamidjaja (2016) Pada fase vegetatif tanaman membutuhkan unsur hara P dan K untuk membantu proses perkembangan seperti lingkar batang.

\section{Jumlah Daun (helai)}

Berdasarkan hasil analisis statistik menunjukkan bahwa pemberian POC kulit nanas tidak berpengaruh nyata terhadap jumlah daun bibit tanaman kelapa sawit pada umur 1, 2 dan 3 BST. Rataan jumlah daun bibit tanaman kelapa sawit dengan pemberian POC kulit nanas dapat dilihat pada tabel 4.

Tabel 4. Rataan jumlah daun bibit tanaman kelapa sawit dengan pemberian POC kulit nanas

\begin{tabular}{cccc}
\hline & \multicolumn{3}{c}{ Jumlah daun (helai) } \\
\cline { 2 - 4 } Perlakuan & $\mathbf{3}$ Bulan setelah tanam \\
\cline { 2 - 4 } & 2 & $\mathbf{2}$ & $\mathbf{3}$ \\
\cline { 2 - 4 } Kontrol & 2 & 2,86 & 4,06 \\
$10 \mathrm{ml} / \mathrm{L}$ & 2 & 2,93 & 4,13 \\
$20 \mathrm{ml} / \mathrm{L}$ & 2 & 3 & 4,2 \\
$30 \mathrm{ml} / \mathrm{L}$ & 2,06 & 3 & 4,2 \\
$40 \mathrm{ml} / \mathrm{L}$ & 2,06 & 3,06 & 4,33 \\
$50 \mathrm{ml} / \mathrm{L}$ & & 4,06 & 44 \\
\hline
\end{tabular}

Keterangan : Angka yang diikuti huruf yang tidak sama pada kolom yang sama berbeda nyata menurut uji DMRT 5\%.

Berdasarkan hasil rata-rata jumlah daun bibitt tanaman yang disajikan pada Tabel 4. dapat dilihat bahwa pemberian POC kulit nanas memberikan pengaruh tidak nyata terhadap jumlah daun bibit tanaman kelapa sawit. Mulai 1 BST dapat dilihat helai daun tertinggi ada pada perlakuan A5 $50 \mathrm{ml} \mathrm{ml} / \mathrm{L}$ dengan nilai rata-rata 4,33 
helai. Sedangkan untuk hasil rata-rata terendah ada pada perlakuan A0 kontrol dengan nilai rata-rata 4,06 pelepah. Hal ini dikarenakan pertumbuhan jumlah daun akan sesuai dengan umur tanamnya. Pangaribuan (2011) mengatakan bahwa jumlah daun tergantung pada umur tanaman karena laju pembentukan daun relatif konstan apabila tanaman ditumbuhkan pada kondisi suhu dan intensitas cahaya yang sama. Menurut Corley et al., (2016) bahwa pada masa pembibitan rata-rata pertambahan jumlah daun kelapa sawit sebanyak 2-3 helai/bulan sampai bibit kira-kira berumur enam bulan.

\section{Panjang Akar (cm)}

Berdasarkan hasil analisis statistik menunjukkan bahwa pemberian POC kulit nanas tidak berpengaruh nyata terhadap panjang akar bibit tanaman kelapa sawit. Rataan panjang akar bibit tanaman kelapa sawit dengan pemberian POC kulit nanas dapat dilihat pada tabel 5 .

Tabel 5. Rataan pajang akar bibit tanaman kelapa sawit dengan pemberian POC kulit nanas.

\begin{tabular}{cc}
\hline \multirow{2}{*}{ Perlakuan } & Umur 3 BST \\
\cline { 2 - 2 } Kontrol & ---Panjang akar (cm)---- \\
$10 \mathrm{ml} / \mathrm{L}$ & $24,26 \mathrm{c}$ \\
$20 \mathrm{ml} / \mathrm{L}$ & $23,40 \mathrm{bc}$ \\
$30 \mathrm{ml} / \mathrm{L}$ & $22,43 \mathrm{~b}$ \\
$40 \mathrm{ml} / \mathrm{L}$ & $21,16 \mathrm{a}$ \\
$50 \mathrm{ml} / \mathrm{L}$ & $20,76 \mathrm{a}$ \\
\hline
\end{tabular}

Keterangan : Angka yang diikuti huruf yang tidak sama pada kolom yang sama berbeda nyata menurut uji DMRT 5\%.

Berdasarkan hasil rata-rata panjang akar tanaman yang disajikan pada Tabel 5. dapat dilihat bahwa pemberian POC kulit nanas memberikan pengaruh nyata terhadap panjang akar bibit tanaman kelapa sawit. Dimana nilai terbaik bagi panjang akar bibit tanaman kelapa sawit terdapat pada perlakuan A5 $50 \mathrm{ml} / \mathrm{L}(20,50 \mathrm{~cm})$ yang berbeda nyata dengan perlakuan A0 kontrol (24,26 cm), A1 $10 \mathrm{ml} / \mathrm{L}(23,40 \mathrm{~cm})$, dan A2 $20 \mathrm{ml} / \mathrm{L}(22,43 \mathrm{~cm})$, namun tidak berbeda nyata dengan perlakuan A3 $30 \mathrm{ml} / \mathrm{L}$ $(21.16 \mathrm{~cm})$ dan A4 $40 \mathrm{ml} / \mathrm{L}$ (8,09 cm). Hasil penelitian Arif (2018) menunjukkan nilai rataan panjang akar $20 \mathrm{~cm}$ termasuk pertumbuhan akar normal.

Unsur hara P yang terkandung pada POC kulit nanas cukup tinggi. Hasil penelitian Suryanto (2016) yang menyatakan bahwa kandungan hara P pada media tumbuh bibit Pre nursery 0,02\% dan 0,09\% tergolong sangat tinggi. Unsur P merupakan komponen utama asam nukleat yang berperan dalam pembentukan dan perkembangan akar bibit tanaman kelapa sawit. Hardjowigeno (2017) menjelaskan bahwa unsur $\mathrm{P}$ memberikan pengaruh yang baik melalui kegitan yaitu pembelahan sel, pembentukan albumin, merangsang perkembangan akar, memperkuat batang dan metabolisme karbohidrat. 


\section{Biomassa Bibit (g)}

Berdasarkan hasil analisis statistik menunjukkan bahwa pemberian POC kulit nanas memberikan pengaruh sangat nyata terhadap bobot basa mamupun bobot kering bibit tanaman kelapa sawit. Rataan bobot basa dan bobot kering bibit tanaman kelapa sawit dengan pemberian POC kulit nanas dapat dilihat pada tabel 6.

Tabel 6. Rataan biomassa bibit tanaman kelapa sawit dengan pemberian POC kulit nanas.

\begin{tabular}{ccc}
\hline \multirow{2}{*}{ Perlakuan } & \multicolumn{2}{c}{----Biomassa bibit $(\mathbf{g})----$} \\
\cline { 2 - 3 } & Bobot basa & Bobot kering \\
\hline Kontrol & $5,59 \mathrm{~d}$ & $1,86 \mathrm{~d}$ \\
$10 \mathrm{ml} / \mathrm{L}$ & $5,50 \mathrm{~cd}$ & $1,92 \mathrm{~d}$ \\
$20 \mathrm{ml} / \mathrm{L}$ & $5,80 \mathrm{c}$ & $2,14 \mathrm{c}$ \\
$30 \mathrm{ml} / \mathrm{L}$ & $6,88 \mathrm{~b}$ & $2,41 \mathrm{~b}$ \\
$40 \mathrm{ml} / \mathrm{L}$ & $7,96 \mathrm{a}$ & $2,74 \mathrm{a}$ \\
$50 \mathrm{ml} / \mathrm{L}$ & $7,91 \mathrm{a}$ & $2,82 \mathrm{a}$ \\
\hline
\end{tabular}

Keterangan : Angka yang diikuti huruf yang tidak sama pada kolom yang sama berbeda nyata menurut uji DMRT 5\%.

Berdasarkan hasil rata-rata bobot basa tanaman yang disajikan pada Tabel 6 . dapat dilihat bahwa pemberian POC kulit nanas memberikan pengaruh nyata terhadap bobot basa maupun bobot kering bibit tanaman kelapa sawit. Dimana nilai terbaik bobot basa bibit tanaman kelapa sawit terdapat pada perlakuan A4 $40 \mathrm{ml} / \mathrm{L}$ (7,96 g) yang berbeda nyata dengan perlakuan A0 kontrol (5,59 g), A1 $10 \mathrm{ml} / \mathrm{L}$ (5,50 g), A2 $20 \mathrm{ml} / \mathrm{L}(6,88 \mathrm{~g})$, dan A3 $30 \mathrm{ml} / \mathrm{L}$ (6,88 g) namun tidak berbeda nyata dengan perlakuan A5 $50 \mathrm{ml} / \mathrm{L}$ (7,91 g). Untuk hasil nilai terbaik bobot kering bibit tanaman kelapa sawit terdapat pada perlakuan A5 $50 \mathrm{ml} / \mathrm{L}(2,82 \mathrm{~g})$ yang berbeda nyata dengan perlakuan A0 kontrol (1,86 g), A1 10 ml/L (1,92 g), A2 20 ml/L (2,14 g), dan A3 30 $\mathrm{ml} / \mathrm{L}(2,41 \mathrm{~g})$ namun tidak berbeda nyata dengan perlakuan $\mathrm{A} 440 \mathrm{ml} / \mathrm{L}(2,62 \mathrm{~g})$. Hal ini terjadi karena berat basah dan berat kering bibit merupakan indikator utama penentuan kualitas bibit yang dipengaruhi oleh tinggi tanaman, jumlah daun, diameter batang, dan pertumbuhan vegetatif tanaman lainnya Hamzah (2014). Perbedaan bobot basah dan bobot kering tanaman antar perlakuan terjadi karena pertumbuhan kelapa sawit yang beragam, sehingga bobot basah dan bobot kering bibit antar perlakuan ikut berpengaruh.

Berat kering tanaman dapat menggambarkan terdapatnya status nutrisi tanaman dan sebagai indikator yang menentukan baik tidaknya suatu pertumbuhan dan perkembangan tanaman sehingga sangat era kaitannya terhadap ketersediaan unsur hara. Sitorus (2014) pun menyatakan bahwa bobot kering ini merupakan salah satu tolak ukuran pertumbuhan dan perkembangan tanaman karena berat kering menggambarkan pada akumulasi senyawa organik yang berhasil disintesis oleh tanaman itu sendiri. Oleh karena itu. bobot kering tanaman dapat dijadikan acuan untuk melihat pengaruh pemberian POC terhadap kualitas bibit tanaman kelapa sawit. 
Bobot kering merupakan salah satu tolak ukur dalam menentukan tingkat metabolisme dari suatu tanaman. Hal ini sesuai dengan pernyataan Afrillah et al., (2015) bahwa akumulasi bahan kering tajuk dan akar menggambarkan kemampuan tanaman dalam menangkap cahaya matahari melalui proses fotosintesis. Selain fosfor $(\mathrm{P})$, unsur hara kalium $(\mathrm{K})$ ini sangat penting dalam menunjang tingginya hasil bobot kering tanaman. Kandungan kalium $(\mathrm{K})$ yang tinggi dapat menyebabkan ion $\mathrm{K}+$ mengikat air dalam tubuh tanaman dengan mempercepat proses fotosintesis. Hasil fotosintesis ini sehingga yang merangsang pembentukan vegetatif menjadi lebih besar dan meningkatkan bobot kering tanaman (Marlina et al., 2018).

\section{PENUTUP}

\section{Kesimpulan}

Berdasarkan hasil penelitian yang telah dilakukan maka dapat disimpulkan sebagai berikut :

1. Pemberian pupuk organik cair kulit nanas memberikan pengaruh nyata hingga sangat nyata terhadap morfologi (tinggi ta

2. naman, diameter batang, dan panjang akar) dan fisiologi (biomassa pertumbuhan) bibit tanaman kelapa sawit (Elaeis guineensis Jacq.) di Pre nursery.

3. Pemberian dosis $50 \mathrm{ml} / \mathrm{L}$ pupuk organik cair kulit nanas memberikan hasil terbaik terhadap parameter tinggi bibit 1-3 BST $(7,06 \mathrm{~cm}, 16,70 \mathrm{~cm}$ dan $22,30 \mathrm{~cm})$, diameter batang 1 BST $(3,48 \mathrm{~cm})$, jumlah daun 1-3 BST (2,06 helai, 3,06 helai dan 4,44 helai), panjang akar $(20,50 \mathrm{~cm})$, dan bobot kering $(2,82 \mathrm{~cm})$.

\section{Saran}

Berdasarkan hasil kesempulan tersebut maka dapat diperoleh saran sebagai berikut :

1. Untuk mendapatkan pertumbuhan bibit tanaman kelapa sawit (Elaeis guineensis Jacq.) di Pre nursery yang lebih baik, dapat digunakan POC kulit nanas dengan dosis $50 \mathrm{ml}$.

2. Perlu dilakukan penelitian lebih lanjut mengenai penggunaan POC kulit nanas 50 $\mathrm{ml}$ di fase pembibitan utama (Main nursery).

3. Perlu dilakukan penelitian lebih lanjut mengenai fermentasi POC kulit nanas agar proses fermentasi lebih cepat kurang dari 1 bulan.

4. Perlu dilakukanya pengamatan luas daun bibit tanaman kelapa sawit (Elaeis guineensis Jacq.) di Pre nursery untuk mengetahui laju proses foto sintesis. 


\section{DAFTAR PUSTAKA}

Afrillah, M., F. E. Sitepu., C. Hanum. (2015). Respons pertumbuhan Vegetatif Tiga Varietas Kelapa Sawit di Pre nursery pada Beberapa Media Tanam Limbah. Jurnal Online Agroteknologi. 3(4). 1289-1295.

Arif, W. (2018). Pemanfaatan Seresah Kelapa Sawit dari Ketiak Tanaman Kelapa Sawit sebagai Media Tumbuh Bibit Kelapa Sawit (Elaeis guineensis Jacq.) di pembibitan Awal. Skripsi. Bekasi (ID): Politeknik Kelapa Sawit Citra Widya Edukasi.

Arizka Panji Setyo, Nurmauli Niar, dan Nurmiaty Yayuk. (2013). Efisiensi Dosis Pupuk NPK Majemuk dalam Meningkatkan Hasil Kedelai Varietas Grobogan. Jurnal Agrotek. Tropika. 1(2) : 179-182.

Corley, R. H. V. dan P.B. Tinker. (2016). The Oil Palm (Fifth Edition). Oxford: Wiley Blackwell. Hlm. 1149.

[DITJENBUN] Pusat Data dan Sistem Informasi Pertanian Sekretariat Jendral Pertanian. 2018. [internet]. [diunduh pada 2021 Maret 12]. Tersedia pada http://ditjenbun.pertanian.go.id

Hardjowigeno, S. (2017). Ilmu Tanah. Jakarta (ID): Akademika Presindo.

Hadisuwito, S. (2012). Membuat Pupuk Organik Cair. Jakarta (ID): PT Agromedia Pustaka. 49 hal.

Hamzah, M. (2014). Studi Metode Pemupukan dan Soil Conditioner terhadap Pertumbuhan Vegetatif serta Efektivitas Serapan Hara Makro Bibit Kelapa Sawit (Elaeis Guineensis Jacq.) Tesis. Fakultas Pertanian Universitas Riau. Pekanbaru.

Hidayat T. (2013). Pertumbuhan dan Produksi sawi (Brassica juncea L) Pada inceptiol dengan Kosong Aplikasi Kompos Tandan Kelapa Sawit. Jurnal Agroteknologi Universitas Riau. 7 (2): 1-9.

Hiderssah, S.M., Simarmata, S. (2014). Pemberian N,P, dan K dan Media Tumbuh Kompos pada Bibit Kelapa Sawit di Pre Nursery. Jurnal Agrotek. 4(1):44-52.

Huda, Muhammad Khoirul. (2013). Pembuatan Pupuk Organik Cair dari Urin Sapi dengan Aditif Tetes (Molasse) Metode Fermentasi. Skripsi. Semarang : Universitas Negeri Semarang.

Istiqomah, N. (2014). Uji Penambahan Pupuk Organik Cair terhadap Pertumbuhan dan Hasil Tanaman Kancang Tanah yang di Budidayakan pada Lahan Lebek. Jurnal Media Sains. 7 (2),185-192.

Makmur. (2018). Respon Pemberian Berbagai Dosis Pupuk Organik Cair terhadap Pertumbuhan dan Perkembangan Cabai Merah. Jurnal Galung Tropika. 7 (1): 1 10. ISSN: 2407-6279.

Manurung. Desri E. (2017). Pengaruh Pemberian Air Kelapa pada Beberapa Batang Atas terhadap Pertumbuhan Bibit Karet. Jurnal. 5 (4): 688.

Marlina, N., Amir, N., dan Palmasari, B. (2018). Pemanfaatan Berbagai Jenis Pupuk Organik Hayati terhadap Produksi Bawang Merah (Allium ascalonicum L.) di 
Tanah Pasang Surut Tipe Luapan C Asal Banyuurip. Jurnal Laban Suboptimal. 7 (1): 74-79.

Netiana. (2019). Pengaruh pemberian pupuk organik cair (POC) kulit buah nanas (Ananas Comosus L. Meer) terhadap Pertumbuhan Tanaman Bayam Merah (Amaranthus Tricolor L.) dan Sumbangannya terhadap Pembelajaran Biologi di SMA. Skripsi. Fakultas Keguruan dan Ilmu Pendidikan. Universitas Sriwijaya. Indralaya.

Pahan, I. (2012). Panduan Lengkap Kelapa Sawit, Manajemen Agribisnis dari Hulu ke Hilir. Jakarta (ID): Penebar Swadaya.

Pahan, I. (2015). Panduan Teknis Budidaya Kelapa Sawit untuk Praktissi Kebun. Jakarta (ID): Penebar Swadaya. 116 hal.

[PASPI]. Palm Oil Agribusiness Strategic Policy Institute. (2014). Industri Minyak Sawit Indonesia Berkelanjutan Peranan Industri Minyak Kelapa Sawit dalam Pertumbuhan Ekonomi, Pembangunan Pedesaan, Pengurangan Kemiskinan, dan Pelestarian Lingkungan. Bogor (ID): PASPI.

Pangaribuan, Y. (2011). Studi Karakter Morfofisiologi Tanaman Kelapa Sawit di Pembibitan terhadap Cekaman Kekeringan. Tesis. Bogor (ID: Institut Pertanian Bogor.

Rina, J,C,A. (2020). Uji Konsentrasi POC Kulit Nanas dalam Beberapa Interval Waktu Pemberian terhadap Pertumbuhan dan Hasil Tanaman Sorgum (Sorghum Bicolor L.) Moench. Skripsi. Fakultas Pertanian Universitas Muhammadiyah Sumatera Utara. Medan (ID). 73 hal.

Setyamidjaja, D. (2016). Kelapa Sawit. Yogyakarta (ID): Kanisius. 80 hal.

Selvia, N., A. Mansyoer dan J. Sjofjan. (2014). Pertumbuhan dan Produksi Tanaman

Sorgum (Sorghum bicolor L.) dengan Pemberian Beberapa Kombinasi Kompos dan Pupuk P. Jurnal. Agrotechnology Departement. Agriculture Faculty. University of Riau. 1(2).

Sitorus, U.K.P., Balonggu, S., Nini, R. (2014). Respons Pertumbuhan Bibit Kakao (Theobroma cacao L.) terhadap Pemberian Abu Boiler dan Pupuk Urea pada Media Pembibitan. Jurnal Online Agroekoteknologi. 2(3):1021-1029.

[SNI] Standar Nasional Indonesia. (2004). Spesifikasi Kompos dari Sampah Organik Domestik. SNI 19-7030-2004: Badan Standarisasi Nasional.

Suryati, D., Anom, E. (2014). Uji Beberapa Konsentrasi Pupuk Cair Azolla (Azolla pinnata) pada Pertumbuhan Bibit Kelapa Sawit (Elaeis guineensis Jacq.) di Pembibitan Utama. Jurnal Online Mahasiswa (JOM) Bidang Pertanian. 1(2): 1-13.

Sulardi. (2019). Pengujian Beberapa Jenis Mulsa dan POC terhadap Pertumbuhan Bibit Kelapa Sawit (Elaeis Guineensis Jacq) di Pre nursery. Journal of Animal Science and Agronomy Panca Budi. 4 (1). 1-7.

Suryanto, T. (2016). Penggunaan Media Tumbuh dan Jenis Wadah Alternatif untuk Pertumbuhan Bibit Kelapa Sawit (Elaeis guineensis Jacq.) di pembibitan. Tesis. Bogor (ID): Institut Pertanian Bogor. 
Susi, S. Surtinah. Rizal, M. (2020). Pengujian Kandungan Unsur Hara Pupuk Organik Cair (POC) Limbah Kulit Nenas. Jurnal. 14(2).

Suwahyono, U. (2011). Petunjuk Praktis Penggunaan Pupuk Organik Secara Efektif dan Efisien. Jakarta (ID): Penebar Swadaya. 140 hal.

Sriagtula R. dan S. Sowmen. (2018). Evaluasi Pertumbuhan dan Produktivitas Sorgum Mutan Brown Midrib (Sorghum bicolor L. Moench) Fase Pertumbuhan Berbeda sebagai Pakan Hijauan pada Musim Kemarau di Tanah Ultisol. Jurnal Peternakan Indonesia. Universitas Andalas. Padang. 20(2):130-144. ISSN: 19071760.

Waruwu, Filsafat. Bilman, Wilman Simanihuruk. Prasetyo, Hermansyah. (2018). Pertumbuhan Bibit Kelapa Sawit di Pre Nursery dengan Komposisi Media Tanam dan Konsentrasi Pupuk Cair Azolla pinnata Berbeda. JIPI. 20(1) : 7-12. 